\title{
18b-glycyrrhetinic acid increases blood pressure in rats through the action on myoendothelial gap junctions
}

\author{
A.S. Khromov, N.V. Dobrelia, I.V. Ivanova, A.I. Soloviev \\ SI "Institute of Pharmacology and Toxicology National Academy of Medical Sciences of Ukraine", \\ Kyiv; e-mail: ndobrelya@gmail.com
}

\begin{abstract}
18b-glycyrrhetinic acid (GA), a pentacyclic triterpenoid found in the roots of licorice plants (Glycyrrhiza glabra), posseses high biological activity, including anti-inflammatory and antimicrobial properties. Additionally, it effectively blocks myoendothelial gap junctions. Our experiments on adult Wistar rats have shown that GA administration via gavage in the dose $0.015 \mathrm{~g}$ per $100 \mathrm{~g}$ of body weight caused a significant increase in arterial blood pressure measured both invasively and non-invasively as early as on the 7th day after beginning of the treatment. Further administration of GA up to 21 days did not change blood pressure significantly. Thoracic aortic rings obtained from GA-treated animals demonstrated a decreased ability to relax in response to acetylcholine (ACh): the maximal dilatory response and the sensitivity of the vascular preparations to $A C h$ measured as $p D_{2}\left(-\log E C_{50}\right)$ were significantly suppressed compared to the relaxant responses of rings from untreated rats. GA externally applied to intact tissues at a concentration of $2 \times 10^{-5} \mathrm{M}$ inhibited the ACh-induced relaxation. The inhibition was more pronounced than that observed in vascular rings obtained from the GA-treated animals. Nevertheless, it was smaller than that observed under combined action of the nitric oxide synthase inhibitor, L-NAME, and indomethacin, indicating that $G A$ affects preferentially EDHF-dependent component of the ACh-induced relaxation. These results may suggest that damage of myoendothelial gap junctions that provide electrical communication between the endothelium and the smooth muscle layers may, at least partially, cause the development of arterial hypertension under GA treatment.

Key words: 18b-glycyrrhetinic acid; myoendothelial gap junctions; NO; EDHF; arterial hypertension.
\end{abstract}

\section{INTRODUCTION}

Over the centuries, licorice root has been widely used as a food ingredient and even as a component in drug therapy. The development of arterial hypertension under the influence of licorice was first described in 1953 [1]. During the last years, new experimental and clinical data indicate that excessive use of licorice leads to the development of arterial hypertension [2-11]. It is clear now that consumption of licorice (liquorice) can lead to dangerously high blood pressure and low potassium levels (hypokalemia).

To create an experimental model of arterial hypertension, for many years we have used in vivo treatment with glycyrrhetinic acid, the active component in licorice. Until now, we (C) A.S. Khromov, N.V. Dobrelia, I.V. Ivanova, A.I. Soloviev could not find a clear explanation of the cellular mechanisms for this phenomenon, except that proposed elsewhere [12], where it was suggested that an excess of licorice leads to development of pseudohyperaldosteronism due to glycyrrhizin binding to the mineralcorticoid receptor, since glycyrrhetic acid has structural similarity to aldosterone.

This point of view undoubtedly has a right to exist. Nevertheless, we would like to test a hypothesis suggesting other cellular mechanisms that determine the development of hypertension with the consumption of active ingredients of licorice root, based on modern concepts of myoendothelial relations in the vascular wall.

It is well known that vascular endothelial cells play an important role in the control of vascular tone. Nitric oxide (NO) is a vasoactive 
mediator released from endothelial cells and it is an important component in the regulation of vascular tone by inhibiting vascular smooth muscle contraction. It has been also found that direct connections exist between smooth muscle cells and endothelial cells. These connections, called gap junction, allow various signal molecules, ions and electrical impulses to directly pass between the cells [13-17]. The myoendothelial gap junctions provide an electrical communication between endothelial and smooth muscle cells, and may be involved in endothelium-dependent vasorelaxation mechanisms associated with the release of endothelium-derived hyperpolarizing factor (EDHF) [18].

The important role of gap junctions in cellular functions was confirmed in experiments with heptanol, octanol or halotane - gap junction blockers in cardiac muscle [19]. It has also been shown that 18 b-glycyrrhetinic acids (GA) is an effective blocker of gap junctions in guinea-pig mesenteric arterioles [15].

Our previous studies demonstrated that gap junctions are a critical point of signaling pathways involved in Rho kinase-dependent $\mathrm{Ca}^{2+}$ sensitization during sustained hypoxic pulmonary vasoconstriction [16].

Licorice roots (Glycyrriza glabra L.) and its products, in turn, are often used in therapy as anti-inflammatory, antispasmodic, antibacterial and expectorant drugs. Since GA is one of its physiologically active components, it may cause some unwanted side effects.

The aim of present study was to estimate possible effect of GA on the vascular tone and blood pressure level in the laboratory animals, as well as to identify the mechanisms underlying the side effects under GA treatment.

\section{METHODS}

All experimental procedures followed the European Convention for the protection of vertebrate animals used for experimental and other scientific purposes (Strasbourg, 1986) and approved by the local Bioethics Committee of the SI "Institute of Pharmacology and Toxicology National Academy of Medical Sciences of Ukraine" (Kyiv, Ukraine). The experiments were performed on 17 adult Wistar rats weighing $240 \pm 10 \mathrm{~g}$. Animals were divided into 2 groups: control and experimental. $18 \beta$-glycyrrhetinic acid as 3\% water suspension was administered via gavage, in dose $0.015 \mathrm{~g}$ per $100 \mathrm{~g}$ of body weight (b.w.) once a day for 21 days. The control animals received distilled water, $0.5 \mathrm{ml} / 100 \mathrm{~g}$ b.w.

Systolic blood pressure (BPs) was measured using rat tail sphygmomanometer S-2 (HSE, Germany) just before administration of the tested substance and on the 7th, 14 th and $21 \mathrm{st}$ day of the treatment. After $21 \mathrm{st}$ day of the GA treatment, the animals were anesthetized with ketamine/xylasine (1 $\mathrm{ml} / \mathrm{kg} \mathrm{b.w.)}$ and surgical preparations consisted in tracheotomy and catheterization of carotid artery was made. BP measurements were performed with the module DBA Type 660 ("HSE", Germany) using polygraph RB-85 ("Nihon Kohden", Japan) and Isotec transducer ("HSE", Germany). The data were digitized with an analog-todigital converter (ADC; "HSE", Germany), accumulated and further processed using the Haemodyn software ("HSE", Germany).

To estimate the endothelium-dependent responses in isolated aortic rings, endotheliumdependent vasodilator, acetylcholine (ACh) was used at concentrations $10^{-9}-10^{-5} \mathrm{M}$.

Experiments were performed on ring preparations ( $1 \mathrm{~mm}$ wide) isolated from rat thoracic aorta. Aortas were obtained from rats sacrificed by cervical dislocation after anesthesia with ketamine/xylasine ( $1 \mathrm{ml} / \mathrm{kg}$ b.w.). The rings were prepared with care to avoid damage to the endothelial layer. Aortic rings were mounted isometrically under a resting tension of $10 \mathrm{mN}$ in a flowing tissue bath, between a stationary stainless steel hook and an isometric force transducer (AE 801, SensoNor A/S, Norten, Norway) coupled to an AD converter LabTrax-4/16 ("World Precision Instruments, Inc.", 
USA). Vascular rings were maintained at $37^{\circ} \mathrm{C}$ and superfused continuously at a rate of $2 \mathrm{ml} /$ min with modified Krebs-bicarbonate buffer solution (see Chemicals and Solutions). They were allowed to equilibrate for $1 \mathrm{~h}$ under resting tension of $3 \mathrm{~g}$ before starting the experiments. All experiments were carried out in the presence of indomethacin $\left(10^{-5} \mathrm{M}\right)$ to exclude any possible involvement of prostacyclin in the endotheliumdependent relaxation response to ACh.

Chemicals and solutions. All chemicals were obtained from "Sigma" (USA). Experiments with isolated vascular preparations were performed at $37^{\circ} \mathrm{C}$ in modified Krebs-bicarbonate buffer solution of the following composition (in $\mathrm{mM}$ ): $\mathrm{NaCl}$ - 133; $\mathrm{KCl}$ - 4.7; $\mathrm{NaHCO}_{3}$ - 16.3; $\mathrm{NaH}_{2} \mathrm{PO}_{4}-1.38 ; \mathrm{CaCl}_{2}-2.5 ; \mathrm{MgCl}_{2}$ - 1.2; glucose - 7.8; pH 7.4.

Statistical analysis. All data are mean \pm s.e.m; $n$ indicates blood pressure measurements or the number of preparations tested. Curves were fitted to Hill equation. Half-maximal effective concentration $\left(\mathrm{EC}_{50}\right)$ values were expressed as $\mathrm{pD}_{2}\left(-\log \mathrm{EC}_{50}\right.$, where $\mathrm{EC}_{50}$ is half-maximum effective concentration). The distribution normality was evaluated with Shapiro-Wilk test. $\mathrm{EC}_{50}$ values and maximal relaxation were compared by the Student's ttest for unpaired data. Comparison of variables obtained by different treatments with basic values were made by one-way ANOVA with a repeated measurements design, and if any significant difference was found, the Scheffe's multiple comparison test was applied. Data were statistically analyzed with MS Exel ("Microsoft", USA) and Origin 9.7 ("OriginLab Corp.", USA).

\section{RESULTS AND DISCUSSION}

In vivo experiments. Systolic blood pressure measured by a non-invasive method in animals treated with GA (day 21) increased significantly on the 7 th day and reached its maximum values on the 21 st day of GA administration (Tables 1).

Measurements of systolic and diastolic pressure in the acute experiment showed higher values of blood pressure increase compared to the non-invasive method (Table 2).

Blood pressure measurements in anesthetized and awake rats clearly indicate that GA administration promoted an increase in both systolic and diastolic blood pressure. Systolic and diastolic blood pressure in GA-treated animals on the 21 st day of the treatment was $28 \%$ and $33 \%$ higher, respectively, compared to control animals. It is important to note that blood pressure levels in the control group of animals did not change significantly throughout the experimental period (up to the 21 st day).

In vitro contractile recordings experiments. Experiments using aortic rings obtained from rats chronically treated with GA. Initially, we examined the responses to Ach in the thoracic aortic rings isolated from rats subjected to chronic oral GA administration. Aortic rings isolated from GA-treated animals demonstrated an impaired endothelial-dependent relaxation to ACh. As shown in Fig. 1, ACh at concentration $10^{-9}-10^{-5} \mathrm{M}$ caused well expressed dosedependent relaxation after phenylephrine $(\mathrm{PhE}$, $10^{-6} \mathrm{M}$ ) induced contraction in thoracic rings isolated from intact animals. Aortic rings obtained from the GA-treated animals demonstrated a significant reduction in endothelial-dependent relaxation to ACh compared to the control rings. The amplitude of maximal relaxation responses to ACh $\left(10^{-5} \mathrm{M}\right)$ decreased from $90.3 \pm 2.1 \%$ in control rings to $60.5 \pm 5.1 \%$ in rings obtained

Table 1. Dynamics of systolic blood pressure (BPs) measured non-invasively in rats following the course of 18ß-glycyrrhetinic acid administration $(M \pm m, n=9)$

\begin{tabular}{|c|c|}
\hline Treatment duration & $\begin{array}{c}\text { Relative changes in } \\
\text { BPs }(\mathrm{mm} \mathrm{Hg})\end{array}$ \\
\hline Initial level & $119.0 \pm 2.2$ \\
7 days & $138.0 \pm 5.3^{*}$ \\
14 days & $132.5 \pm 2.2^{*}$ \\
21 days & $136.7 \pm 3.8^{*}$ \\
\hline
\end{tabular}

Note: $*$ The data statistically differ from the initial level, $\mathrm{P}<0.01$. 
Table 2. Effect of the 3 weeks course of $18 \beta$-glycyrrhetinic acid administration on systolic and diastolic blood pressure measured invasively in rats $(\mathrm{M} \pm \mathbf{m})$

\begin{tabular}{|l|c|c|c|}
\hline \multirow{2}{*}{ Treatment } & \multicolumn{3}{|c|}{ BP (mm Hg) } \\
\cline { 2 - 4 } & Systolic & diastolic & mean \\
\hline
\end{tabular}

$\begin{array}{lccr}\text { Control group }(\mathrm{n}=8) & 138.0 \pm 4.4 & 89.8 \pm 7.1 & 105.9 \pm 7.2 \\ \text { GA-treated rats }(\mathrm{n}=9) & 176.9 \pm 10.0^{*} & 119.5 \pm 8.9^{*} & 143.7 \pm 10.2^{* *}\end{array}$

Note: *The data statistically differ from the control group, $\mathrm{P}<0.01$. **The data statistically differ from the control group, $\mathrm{P}<0.05$.

from GA-treated rats $(\mathrm{P}<0.01, \mathrm{n}=14)$. The $\mathrm{pD}_{2}$ for control and experimental groups were also significantly different $(-7.8 \pm 0.14)$ and $(-7.3 \pm$ $0.06),(\mathrm{P}<0.05, \mathrm{n}=14)$, respectively, supporting that sensitivity of vascular tissues to ACh had significantly decreased following GA treatment.

Nitric oxide synthase inhibitor, $L-\mathrm{N}^{\omega}$ nitroarginine methyl ester (L-NAME, $3 \times 10^{-4} \mathrm{M}$ ) additionally suppressed $\mathrm{ACh}$-induced relaxation up to $12 \pm 1.3 \%$ of the maximal amplitude of contraction evoked by $\mathrm{PhE}(\mathrm{P}<0.01, \mathrm{n}=14)$.

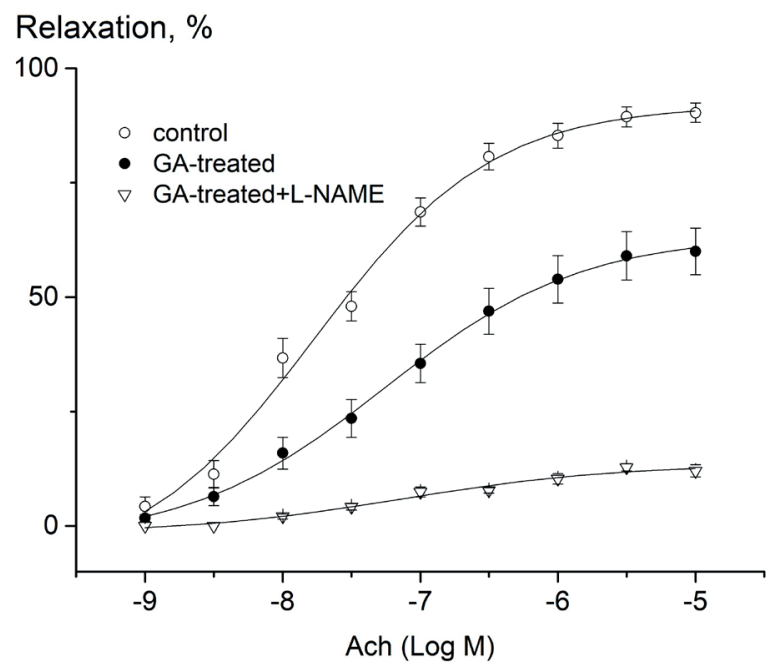

Fig. 1. Cumulative concentration-response curves to acetylcholine obtained in aortic rings from GA-treated rats: $\circ$ - intact preparations; $\bullet$ - vascular rings obtained from the rats treated with GA (18b-glycyrrhetinic acid, $0.015 \mathrm{~g}$ per 100 $\mathrm{g}$ b.w.) for 21 days; $\nabla$ - rings obtained from GA-treated rats and incubated in the presence of N-nitro-L-arginine methyl ester (L-NAME, $3 \times 10^{-4} \mathrm{M}$ ). All rings were pre-contracted with phenylephrine $\left(10^{-6} \mathrm{M}\right)$. Results are expressed in percent of the contraction evoked by phenylephrine. All experiments were performed in the presence of indomethacin $\left(10^{-5} \mathrm{M}\right)$. Concentration-response curves were fitted by the Hill equation
Experiments using intact tissues with direct addition of GA to the organ bath. To clarify the GA effect further, we performed the experiments with intact vascular tissues. GA at a concentration $2 \times 10^{-5} \mathrm{M}$, being added to the organ bath directly for $7 \mathrm{~min}$ before $\mathrm{ACh}$ application, caused a prominent inhibition of the response to $\mathrm{ACh}$ in control rat rings (from $90.3 \pm 2.1$ to $45.9 \pm 2.8 \%$ of maximal AChinduced relaxation in contraction caused by $\mathrm{PhE}$, $\mathrm{n}=14$, Fig. 2).

L-NAME $\left(3 \times 10^{-4} \mathrm{M}\right)$ decreased the relaxant response to $\mathrm{ACh}$ up to $18.9 \times 0.5 \%$, but did

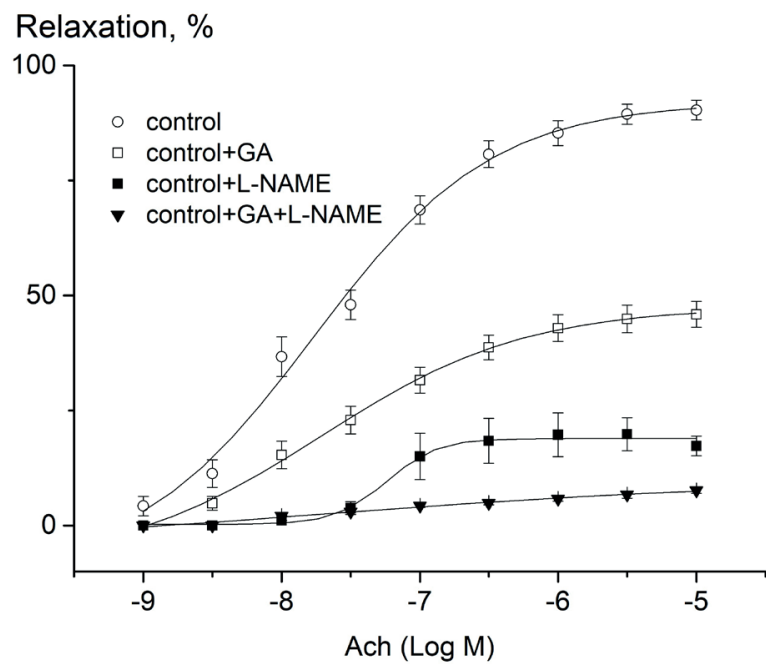

Fig. 2 Cumulative concentration-response curves to acetylcholine performed on intact aortic ring from healthy rats obtained before (०) and after $7 \mathrm{~min}$ of GA application ( $\square$ ); GA plus L-NAME ( $\boldsymbol{\nabla})$ and L-NAME alone ( $\mathbf{\square})$. All rings were precontracted with phenylephrine $\left(10^{-6} \mathrm{M}\right)$. Results are expressed in percent of the contraction evoked by phenylephrine. All experiments were performed in the presence of indomethacin $\left(10^{-5} \mathrm{M}\right)$. Concentration-response curves were fitted by the Hill equation 
not cause a complete block of ACh-induced relaxation in intact aortic rings, suggesting a significant endothelium-derived hyperpolarizing factor (EDHF)-mediated component. The addition of L-NAME $\left(3 \times 10^{-4} \mathrm{M}\right)$ in combination with GA $\left(2 \times 10^{-5} \mathrm{M}\right)$ to the bath solution dramatically reduced endothelium-dependent relaxation of rings obtained from healthy animals (from $90.3 \pm 2.1$ to $7.6 \pm 0.6 \%$ of maximal relaxation amplitude to $\mathrm{ACh}, \mathrm{n}=14$ ).

It is interesting to note that the similar effects of L-NAME were observed in tissues obtained from GA-treated animals (Fig. 1).

The endothelium-dependent vascular responses in hypertension are well known to be markedly depressed in both animals and humans [20-23]. The main finding of present study is that orally administered GA or drugs that contain this active compound in a sizable concentration may lead to unwanted vascular malfunction and development of arterial hypertension. To shed light on possible mechanisms of GA side effects, we have compared the effects of GA on endothelium-dependent vascular responses in intact tissues and in tissues isolated from GAtreated animals.

It is known that the ACh-induced relaxation of blood vessels can be attributed to the release of three main components: endothelium-derived relaxing factor (EDRF/NO), prostacyclin and endothelium-derived hyperpolarizing factor (EDHF). It is generally accepted that these components can be separated in experiment using nitric oxide syntase blockers (e. g., L-NAME) and inhibitors of prostacyclin synthesis, such as indomethacin.

We performed experiments that evaluated of ACh-induced endothelium-dependent responses using isolated vascular preparations. It is important to note that indomethacin was present in all isolated tissue experiments to block prostacyclin production.

It has been shown that at least in some vascular beds the EDHF phenomenon is accounted by transmission of a hyperpolarizing electrical signal from the endothelium to the underlying smooth muscle cells through intercellular gap junction $[17,18,24]$. We suppose that GA affects mainly the mechanisms associated with the transmission of EDHF signal from the endothelium to the underlying smooth muscles.

Our results showed that L-NAME plus indomethacin reduced the amplitude of AChinduced relaxation in intact aortic tissues by about $80 \%$, indicating rather small degree of expression of the EDHF component in AChinduced relaxation in the aortas from healthy rats. At the same time, the maximum amplitude of ACh relaxation in the aorta of GA-treated rats was reduced by about $30 \%$. This indicates that GA can act on the regulatory mechanisms of vascular tone not only through the pathway associated with the EDHF component, but also partially (by about 10\%) through the EDRF/NO component. Thus, the studies with L-NAME applied on intact and GA-treated vascular preparations suggest that GA selectively inhibits stable EDHF-dependent component of ACh-induced vascular relaxations, while the $\mathrm{NO}$-dependent component of relaxation is less affected.

The addition of GA to the organ bath with intact aortic preparations decreased the relaxation amplitude more strongly compared to the effect achieved following chronic in vivo GA-treatment. Therefore, GA may be considered as an inhibitor of EDHF signal propagation as a result of uncoupling of the connection between the endothelium and smooth muscle cell layers in the vascular wall [25]. It is likely that longterm GA administration resulted in inhibition of both EDHF (preferentially) and EDRF/NO component (in a lesser degree) of ACh-induced dilatation, leading to development of endothelial dysfunction that, in turn, causes an increase in arterial blood pressure level.

Our results indicated that EDHF-dependent component of ACh-stimulated relaxation of rat thoracic aorta is relatively small and averages about $20 \%$ of the total dilator response. However, it is an important mechanism for 
normal vascular function. In particular, EDHF is a rather stable component of ACh-induced relaxation under oxidative stress since gradiation selectively inhibits the $\mathrm{NO}$-dependent pathway, while EDHF-dependent component of the relaxation remains resistant and maintains low endothelium-dependent responses [26]. Interestingly, non-invasive measurement of systolic blood pressure in irradiated (6 Gy) rats showed that on the 9th day of the post-irradiation period, blood pressure also increased significantly due to dysfunction of endothelial-dependent mechanisms of vascular tone regulation [27].

\section{CONCLUSIONS}

Our results suggest that a significant increase in blood pressure in rats treated with $18 \beta$-glycyrrhetinic acid could be caused by a disruption of electrical connection between endothelial and smooth muscle layers in the vascular wall, specifically damage to myoendothelial gap junctions that leads to the development of unwanted blood pressure.

The authors of this study confirm that the research and publication of the results were not associated with any conflicts regarding commercial or financial relations, relations with organizations and/or individuals who may have been related to the study, and interrelations of co-authors of the article.

\section{О.С. Хромов, Н.В. Добреля, І.В. Іванова,}

\section{А.І. Соловйов}

\section{8ß-ГЛЦИРЕТИНОВА КИСЛОТА ПІДВИЩУС ТИСК КРОВІ У ЩУРІВ, ВПЛИВАЮЧИ НА МІОЕНДОТЕЛІАЛЬНІ КОНТАКТИ}

ДУ “Інститут фармакології та токсикологї НАМН України”, Київ; e-mail: ndobrelya@gmail.com

$18 \beta$-гліциретинова кислота (GA) - пентациклічний тритерпеноїд, що міститься в коренях солодки (Glycyrrhiza glabra), має високу біологічну активність, включаючи протизапальну та протимікробну дію, а також здатність блокувати міоендотеліальні контакти. Наші експерименти на дорослих щурах лінії Вістар показали, що внутрішньошлункове введення раз на добу GA в дозі 0,015 г на 100 г маси тіла спричинює значне підвищення артеріального тиску, вимірюваного неінвазивно $з$ 119,0 $\pm 2,2$ до 138,0 $\pm 5,3$ мм рт. ст. вже на 7-й день після початку курсу. Подальше іiі введення до 21-го дня не призводило до істотних змін цього показника. Кільця грудної аорти тварин, які отримували GA, демонстрували знижену здатність розслаблюватись у відповідь на дію ацетилхоліну. Максимальна дилатаційна реакція і чутливість судинних препаратів до ацетилхоліну, виражена як $\mathrm{pD}_{2}\left(-\log \mathrm{EC}_{50}\right)$, були значно пригнічені $(60,5 \pm$ $5,1 \%$ i $7,3 \pm 0,06)$ порівняно $з$ відповіддю на релаксант тканин інтактних тварин $(90,3 \pm 2,1 \%$ та $-7,8 \pm 0,14)$ відповідно. GA при застосуванні для інкубації тканин інтактних щурів у концентрації $2 \cdot 10^{-5}$ ммоль/л пригнічувала індуковану ацетилхоліном релаксацію більшою мірою, ніж це спостерігалося на кільцях судин тварин, які отримували лише GA. Однак таке зменшення було менш вираженим, ніж за умов дії інгібітора синтази оксиду азоту L-NAME та індометацину. Це вказує на те, що GA впливає переважно на EDHF-залежний компонент релаксації, викликаної дією ацетилхоліну. Наші результати вказують на те, що пошкодження міоендотеліальних щілинних контактів, які забезпечують електричний зв'язок між ендотелієм i шаром гладеньких м'язів, може, принаймні частково, брати участь у розвитку артеріальної гіпертензії, викликаної введенням GA.

Ключові слова: 18ß-гліциретинова кислота; міоендотеліальні контакти; NO; EDHF; артеріальна гіпертензія.

\section{А.С. Хромов, Н.В. Добреля, И.В. Иванова, А.И. Соловьев \\ 18ß-ГЛИЦИРРЕТИНОВАЯ КИСЛОТА ПОВЫШАЕТ ДАВЛЕНИЕ КРОВИ У КРЫС, ДЕЙСТВУЯ НА МИОЭНДОТЕЛИАЛЬНЫЕ КОНТАКТЫ}

18ß-глицирретиновая кислота (GA) - пентациклический тритерпеноид, содержащийся в корнях солодки (Glycyrrhiza glabra), обладает высокой биологической активностью, включая противовоспалительное и противомикробное действие, а также способен блокировать миоэндотелиальные контакты. Наши эксперименты на взрослых крысах линии Вистар показали, что внутрижелудочное введение один раз в сутки GA в дозе 0,015 г на 100 г массы тела вызывало значительное повышение артериального давления, измеренного неинвазивним методом c $119,0 \pm 2,2$ до $138,0 \pm 5,3$ мм рт. ст. уже на 7-й день после начало купса. Дальнейшее ее введение вплоть до 21-го дня эксперимента не приводило к существенным изменениям этого показателя. Кольца грудной аорты животных, получавших GA, демонстрировали пониженную способность расслабляться в ответ на действие ацетилхолина. Максимальная дилатационная реакция и чувствительность сосудистых препаратов к ацетилхолину, выраженная как 
$\mathrm{pD}_{2}\left(-\log \mathrm{EC}_{50}\right)$, были значительно подавлены $(60,5 \pm 5,1 \%$ и $7,3 \pm 0,06)$ по сравнению с ответом на релаксант тканей интактных животных $(90,3 \pm 2,1 \%$ и $-7,8 \pm 0,14)$ соответственно. GA при использовании для инкубации тканей здоровых крыс в концентрации $2 \cdot 10^{-5}$ ммоль/л подавляла индуцированную ацетилхолином релаксацию в большей степени, чем это наблюдалось на кольцах сосудов животных, получавших только GA. Однако это подавление было менее выраженным, чем при действии ингибитора синтазы оксида азота L-NAME и индометоцина, что указывает на преимущественное влияние GA на EDHF-зависимый компонент релаксации, вызванной ацетилхолином. Наши результаты могут указывать на то, что повреждения миоэндотелиальных щелевых контактов, обеспечивающих электрическую связь между эндотелием и слоем гладких мышц, по крайней мере, частично, вовлечены в развитие артериальной гипертензии под влиянием GA.

Ключевые слова: 18 $\beta$-глицирретиновая кислота; миоэндотелиальные контакты; NO; EDHF; артериальная гипертензия.

\section{REFERENCES}

1. Harders H, Rausch-Stroomann JG. Hypertension caused by chronic licorice poisoning; warning on uncontrolled selftreatment. Munch Med Wochenschr. 1953;95(20):580-2.

2. Walker BR, Edwards CR. Licorice-induced hypertension and syndromes of apparent mineralocorticoid excess. Endocrinol Metab Clin North Am. 1994;23(2):359-77.

3. Flores-Robles BJ, Sandoval AR, Dardon JD, Blas CA. Lethal liquorice lollies (liquorice abuse causing pseudohyperaldosteronism). BMJ Case Rep. 2013 Sep 19;2013:bcr2013201007.

4. Ottenbacher, R., Blehm, J. An unusual case of licoriceinduced hypertensive crisis. South Dakote Med. 2015;68(8):346-9.

5. Hautaniemi EJ, Tahvanainen AM, Koskela JK, Tikkakoski AJ, Kähönen M, Uitto M, Sipilä K, Niemelä O, Mustonen J, Pörsti IH. Voluntary liquorice ingestion increases blood pressure via increased volume load, elevated peripheral arterial resistance, and decreased aortic compliance. Sci Rep. 2017;7(1):10947.

6. Falet J-P, Elkrief A, Green L. Hypertensive emergency induced by licorice tea. Can Med Assoc J. 2019;191(21): E581-E583.

7. Rossi T, Vampa G, Benvenuti S, Ruberto A, Baggio G, Castelli M. Effect of $18 \mathrm{~B}$ glycerrhetinic acid on systolic blood pressure in normotensive rats. Pharmacol Res. 1992;26 (1):45.

8. Kageyama Y, Suzuki H, Saruta T. Role of glucocorticoid in the development of glycyrrhizin-induced hypertension. Clin Exp Hypertens. 1994;16(6):761-78.

9. Ruszymah BH, Nabishah BM, Aminuddin S, Khalid BA. Effects of glycyrrhizin acid on right atrial pressure and pulmonary vasculature in rats. Clin Exp Hypertens. 1995;17:575-91.
10. Sigurjonsdottir HA, Franzson L, Manhem K, Ragnarsson J, Sigurdsson G, Wallerstedt S. Liquorice-induced rise in blood pressure: a linear dose-response relationship. J Hum Hypertens. 2001;15:549-52.

11. Allcock E, Cowdery J. Hypertension induced by liquorice tea. BMJ Case Reports. 2015; bcr2015209926.

12. Sonita B, Mooney J, Gaudet L, Touyz RM. Pseudohyperaldeosteronism, liquorice and hypertensip. J Clin Hypertens. 2008;10:2.

13. Von der Weid PY, Beny JL. Simultaneous oscillation in the membrane potential of pig coronary artery endothelial and smooth muscle cells. J Physiol. 1993;471:13-24.

14. Beny JL. Electrical coupling between smooth muscle cells and endothelial cells in pig coronary arteries. Pflügers Arch. 1997;433:364-7.

15. Yamamoto Y, Fukuta H, Nakahira Y, Suzuki H. Blockade by $18^{\mathrm{b}}$-glycyrrhetinic acid of intercellular electrical coupling in guinea-pig arterioles. J Physiol. 1998;511:501-8.

16. Kizub I, Strielkov I, Shaifta I, Becker S, Prieto-Lloret J, Snetkov V, Soloviev A, Aaronson P, Ward J. Gap junctions support the sustained phase of hypoxicpulmonary vasoconstriction by facilitating calcium sensitization. Cardiovascul Res. 2013;99:404-11.

17. Xu H L, Santizo RA, Baughman VL, Pelligrino DA. ADPinduced pial arteriolar dilation in ovariectomized rats involves gap junctional communication. Am J Physiol Heart C. 2002;283:H1082-91.

18. Coleman HA, Tare M, Parkington HC. Myoendothelial electrical coupling in arteries and arterioles and it's implications for EDHF. Clin Exp Pharmacol Physiol. 2002;29:630-6.

19. Spray DC, Burt JM. Structure-activity relations of the cardiac gap junctions channel. Am J Physiol. 1990;258:195-205.

20. Winquist RJ, Bunting PB, Baskin EP, Wallace AA. Decreased endothelium-dependent relaxation in New Zeland genetic hypertensive rats. J Hypertens. 1984;2:541-5.

21. Panza JA, Quyyumi AA, Brush JE, Epstein SE. (1990). Abnormal endothelium-dependent vascular relaxation in patients with essential hypertension. N Eng J Med. 1190;323:22 - 7

22. Soloviev AI, Stefanov AV, Bazilyuk OV, Sagach VF. Phospholipid vesicles (liposomes) restore endotheliumdependent cholinergic relaxation in thoracic aorta from spontaneously hypertnesive rats. J Hypertens. 1993;11:623-7.

23. Soloviev A, Parshikov AV, Stefanov AV. Evidence for the involvement of protein kinase $\mathrm{C}$ in depression of endothelium-dependent vascular responses in spontaneously hypertensive rats. J Vascul Res. 1998; 35:325-31.

24. Dora KA, Sandow SL, Gallagher NT, Takano H, Rummery NM, Hill CE, Garland CJ. Myoendothelial gap junctions may provide the pathway for EDHF in mouse mesenteric artery. J Vascul Res. 2003;40: 480-90.

25. Yamamoto Y, Imaeda K, Susuki H. Endothelium- 
18b-glycyrrhetinic acid increases blood pressure in rats through the action on myoendothelial gap junctions

dependent hyperpolarization and intercellular electrical coupling in guinea-pig mesenteric arterioles. J Physiol. 1999;514:505-13.

26. Soloviev A, Tishkin S, Parshikov A, Ivanova I, Goncharov E, Gurney A. Mechanisms of endothelium dysfunction after ionized radiation: selective impairment of the nitric oxide component of endothelium-dependent vasodilation.
Br J Pharmacol. 2003;138:837-42.

27. Soloviev A, Stefanov A, Tishkin S, Khromov A, Parshikov A, Ivanova I, Gurney A. Saline containing phosphatidylcholine liposomes possess the ability to restore endothelial function damaged resulting from $\gamma$-irradiation. J Physiol Pharmacol. 2002;53(4):12132.

Received 04.06.2021 